\title{
WORK-BASED LEARNING IN PROFESSIONAL EDUCATION OF LATVIA: HISTORICAL DEVELOPMENT
}

\author{
Ilze Briža, Anita Pipere \\ Daugavpils University, Latvia
}

\begin{abstract}
The Latvian labor market has been facing the problem of a quality labor force shortage for several years now. The acquisition of demanded specialties in Latvia is possible in the framework of professional education, which is offered at three levels - the level of primary education, professional secondary education, and professional higher education. Since 2015, work-based learning has been introduced in the professional education of Latvia, serving as a measure for the economic enhancement for the entry of quality labor force into the labor market. As a part of this initiative, educational institutions in cooperation with employers develop curricula that match the requirements of the labor market. This learning model is based on an example of a higher professional education model, where practical skills are acquired mostly during the students' field practice. To conduct the empirical research on work-based learning in higher professional education, at first, it is necessary to look at the historical aspects of this learning model. The given article provides historical evidence, describing the historical development of work-based learning in professional education in Latvia. The beginnings of work-based learning in Latvia date back to the 14-15th century, but for the first time given form of education in its contemporary meaning has been introduced in Soviet times, as historical sources show the calls for get to know work experience as an integral part of communist work schools. After the regaining of independence, Latvia focuses on building the democratic education system, and since 2015 work-based learning is explicit in the Law on Professional Education as a specific form of education. Since its inception, work-based learning has reflected the public's perceptions of the necessary specialties in the labor market.
\end{abstract}

Keywords: higher education, lifelong education, professional education, work-based learning, working environment.

\section{Introduction}

Historically developed and constantly solved topical problems in the modern economy - lack of skilled labour force, the solution has already been partially implemented in Latvia. Vocational education at a secondary 
level can also be implemented as a work-based learning process. It is a flexible form of education, which is implemented both in a vocational education institution and in a company. Work-based learning in Latvian vocational education was officially introduced in 2015 when there was a shortage of more than 50,000 different professionals. It is this form of education that has played a central role in Latvia's efforts to cope with the consequences of the economic crisis in Europe (Cedefop, 2015). The abovementioned model is related to the integration of students into the working environment, ensuring timely cooperation between the prospective employee and the employer and avoiding the transition period between studies and the performance of direct work duties since the student is already in the working environment during the study period. In such an educational model, the employer himself or herself can direct the prospective employee towards the acquisition of the necessary knowledge and skills.

The justification for the inclusion of such a form of study/study at all levels of vocational education, including higher vocational education, is the Sustainable Development Strategy of Latvia until 2030, which provides for improvement and accessibility of the quality of education, stressing the need to improve support measures that would motivate for employers to invest in the development of resources of the skilled labour force (Latvia 2030, 2010). The report of the Ministry of Economics of the Republic of Latvia on the support program developed by the public sector to facilitate the application of conditions for attracting highly qualified specialists also concluded that the lack of highly qualified specialists limits the growth of the Latvian economy, the growth of the productivity of enterprises and attraction of investments, and thus the formation of well-paid jobs (2018, February 20).

Although work-based education officially got its name in Latvia only in 2015, such a model has existed in Latvian and European education systems in the past, using terms such as "oil training" "project learning" "learning in the workplace" etc. It is learning in the workplace that is the basis for work-based learning. In its development, such a form of education has always reflected the interrelationship between economics and education, the linking theory and practice in the educational process and linking the social and institutional division of the dual training system (Wagner \& Childs, 2000). There can be talking about work-based educational process as indirect, unforeseen, opportunistic and unstructured learning without a teacher. At the same time, it is a learner's practice under the guidance of a mentor or supervisor. It is learning led by learners themselves, not academic staff (Attenborough et al., 2019).

Meanwhile, the introduction of work-based studies in such fields as teachers (2020, January 21). and nurses' vocational education has begun 
in higher vocational education in Latvia. Since September 2021, as a result of the reform of nursing education, the acquisition of this profession will also be rooted in the concept of work-based studies, which stipulates that at least $60 \%$ of the entire study process will take place in a clinical environment (2019, July 3).

The lack of need workers and its link with the educational process is currently relevant to research problems not only in Latvia, Europe but also worldwide. According to various European studies on the work-based study process introduced in vocational education, its impact on labour force qualifications and the entry of the worker into the relevant labour market (Attenborough et al., 2019, Abbot et al., 2019; Moldovan, 2019), such a form of study promotes motivation to acquire the skills necessary for the relevant profession and ensures that specialists meeting the requirements of employers enter the labour market.

Work-based learning can be viewed in close association with vocational education at different levels of its implementation. The aim of the article is to provide a brief insight into the historical development of teaching terminology and the process itself in Latvia based on the working environment. The first part of the article presents the development of terminology related to work-based learning and historical evidence of the use of the concept of such a learning model. The second part of the article examines the historical development of work-based learning in the context of vocational education. In order to find out the historical aspects related to the research topic, historical evidence will be analyzed, describing the development of work-based learning, which over the years has led to the introduction of such a model in Latvia.

\section{Development of terminology related to work-based teachings}

About work-based learning as a unique form of education that includes different operational strategies, such as operational learning, operational science and practice communities, combining it all into a single system, writes Joseph A. Raelins (Raelin, 2008), a researcher at Northeastern University. He talks about work-based learning as combining knowledge and action in the workplace. The author believes that this type of education is learning with others, putting victory on the inclusive model, which is considered effective in the acquisition of all professions. Author sees learning as creating, adapting, and deepening knowledge. Without such a concept of learning, it is impossible to change the meaning and self-functioning of one's professional activity. Thus, learning nowadays has already become a natural way of improving any organization and acquiring a profession. Work-based learning combines theory with practice and knowledge with experience (Raelin, 2008). 
Theoretical interpretations of work-based education in the world have so far shown similar terminology. In 1918, educational researchers refer to such a learning model as the "project method" (Kilpatrick, 1918). In 1938, the renowned educational theorist John Dewey writes about the development of "experimental learning." He has already talked about including "real life" in the learning process during this period, encouraging students to explore physical and technical applications wherever they can be found to develop a technical and critical understanding of the environment of their chosen profession (Dewey, 1938). Fifty years later, such a form of education is also referred to as "productive activities" (Wagner \& Childs, 2000). However, on-the-job training has always been linked directly to the acquisition of skills required by the profession. This is also the reason for the use of the term 'polytechnic education' (Beck, 1990) in the historical development of work-based learning. Despite the terminology used to describe such an educational model, the aim of such a model has always been to use educational practices to involve learners more quickly in socially pro-active and income-generating activities in potential workplaces (Wagner \& Childs, 2000).

Turning to the use of terminology in the Latvian context, it should be noted that term "work-based learning" in Latvian laws and regulations can be found only in the Vocational Education Law, which states that such study process may be implemented as a separate form of vocational education training (Vocational Education Law, 1999). In higher vocational education such a model is not mentioned separately in-laws and regulations. However, in research and educational practice in Latvia, the term "work-based learning" has already taken root, although such a model of education has changed its name over time. The unifying element, despite the use of different terminology in different time stages, has always been the goal - to get the student into the appropriate working environment during the study period, thus stimulating the entry of specialists into the labour market.

\section{Historical development of work-based learning in the context of vocational education in Latvia}

The beginnings of work-based learning in Latvia can be observed already in the 14th-15th century. In the beginning, the oil lasted 1-2 years, but at the master's discretion it could take up to 10 years (National Encyclopedia, 2021). This form of learning reflects, in a way, a situation in which whoever knows the position educates young craftsmen using their work experience. Nowadays, within the framework form of education based on the working environment, we can also talk about educational practices in educational institutions. 
In the $19^{\text {th }}$ years, the history of Latvia is marked by the stage of freeing farmers, when the main task of educational institutions was to educate farmers to slink with the economic and political interests of landlords. Thus, peasant schools were created, where peasants next to the elimination of illiteracy, teacher training, promotion of a social way of life discussion of topical political and domestic issues, promotion of writing and singing culture, transferred their practical knowledge in rural work to young people, thus creating descendants of the position (Kestere, 2019; Latvijas Vēstnesis, 2020). It is in the $19^{\text {th }}$ century that vocational education is considered to be the stage of the emergence of vocational education as a separate form of education when various educational institutions are established in Latvia for the acquisition of a specific position - craft schools. In the $19^{\text {th }}, 1930$ 's and 1950's years, the first craft schools were opened in Latvia - vagary school, servant's school, Trikata meadows breeding school. The establishment of all these educational institutions has been based on the influence of social, economic, political and cultural factors over time, the development of which led to a rapid increase in the need for qualified professionals (National Encyclopedia, 2020). In 1861, the first educational institution of this type - Riga Polytechnic School - was opened, the purpose and main task of which was to provide theoretical and practical education to prepare specialists of higher qualification in the manufacturing, technical and commercial sectors, thus contributing to the economic growth and modernisation of the Baltic region (National Encyclopedia, 2021). At the end of the $19^{\text {th }}$ century, in the context of vocational education in Latvia, workers' associations contributed, which, among other things, dealt with educational issues. (Kestere, 2019).

In the context of vocational training, work-based learning has been implemented to some degree since the $19^{\text {th }}$ year, when the first schools are established in Latvia with the aim of facilitating the entry of appropriate professionals into the labour market. To ensure this, young apprentices are sent to training with already experienced crafts. In later years, such a form of education is associated with manufacturing enterprises where training places are organized.

Simultaneously with the establishment of the Latvian state in the $20^{\text {th }}$ century the beginning is the period when vocational education, interacting with adult education, becomes a part of the state education policy, for which pragmatic goals are set - practical acquisition of knowledge necessary for the economy and vocational education (Statistics of Latvian culture. 1918-1937, 1938). In the early 1990s, vocational education institutions in Latvia were established to meet the requirements of the economy. The lack of a qualified labour force in Latvia is considered to be the reason for the establishment of such schools. In the history of Latvia, publications 
on this problem can be found since the 1990s. In the 1920s, when production work, which requires highly skilled labour or, in the words of that time, a lot of labour force and knowledge, is mentioned as one of the basic tasks of rebuilding the country, along with national thinking. In order to provide such specialists at a national level, it is necessary to start searching for the solution to the problem already during school hours, in addition to general education, also providing a place for acquiring practical knowledge in the amount of at least one hour a week (Dindan, 1921).

20 years later, despite the economic crisis and the time of the Soviet occupation of Latvia, vocational education is still relevant for the development of the national economy. In 1941, the magazine "Work" where, among other things, there is talk of new professionals entering in the labor market, the report of the leader of the Soviet era A. Scherbakov was published. It takes the view that a situation where unsuccessful working-class workers enter the labour market after the learning process cannot be tolerated. As a solution to the problem at that time, the Supreme Council of the USSR started sending more than 600,000 young people to craft and railway schools and various factories. This was done with the aim of facilitating the entry of adequately trained workers into the labour market. This would receive new skilled workers willing to 'give up their professional knowledge, in the words of that time, 'to give back for the sake of strengthening the homeland and its grandeur' (Scherbakov, 1941). In the working environment, this problem is still relevant a few years later, when a 1944 meeting of trade union activists highlights the fact that the problem of the skilled labour force is topical. To solve this problem, it is tasked to assign unskilled workers to the qualified ones for the acquisition of qualifications and improvement of skills (Zemgale communist, 1944).

The successful link between vocational training and the emergence of economic, socially critical thinking in relation to the corresponding "qualifications" are also discussed in historical evidence 20 years later. In 1958, the newspaper "Soviet Youth" writes about work as a basis for learning and knowledge. During this period, the choice of students to acquire the particular profession is mentioned as a topical problem of vocational education, i. e. often this choice does not coincide with the desire to perform the duties of the corresponding position. Thus, there can be the discussion of the acquisition of knowledge and skills that are incomplete and frivolous, which in turn does not contribute to a positive attitude towards work. It is believed that society should be involved in the process of educating every individual by sending each pupil to a production facility during the summer holidays. Thus, by getting into real working life in a timely manner, the young people themselves would encourage self-schooling and the desire or, accordingly, unwillingness to work within this profession. This would be the 
real rapprochement with real working life. At the same time, the publication raises the problem - students regularly delay lectures on the reason for the performance of work duties. Educational institutions during this period invite employers to provide information on how many graduates end up working in the chosen field. This would show the importance of combining study time and work within the framework of studies, bringing students closer to real working life. Problems: lack of skilled labour and non-entry of graduates into the labour market for the profession. At that time, the solution is offered to professional learners to work at the possible next place of work (Andrejsons, 1958) for at least a year during their studies.

Two decades later in historical evidence, it is already possible to see the implementation of the solution to the a fore mentioned problems in practice, as the 1976 magazine "October Flag" describes the creation of a classroom in a potential workplace, thus solving a national problem - the qualitative and appropriate skills of students for the performance of trade. After the establishment of the classroom in a factory, the productivity of students is evaluated 7\% higher. Getting to know and use the experience of first - timers during these years of history has already become an integral part of the Communist Work Schools program (Turkovsky, 1976).

With the beginning of a new phase in the history of Latvia - the reconstruction phase of an independent, democratic republic, one of the most important tasks of the restored state is mentioned precisely the arrangement and improvement of the education system with the aim of preparing citizens for life in a democratic society. The education guidelines also determine, among other things, the development and improvement of professional abilities (Latvijas Vēstnesis, 1995), thus contributing directly to the development and growth of vocational education.

The development of vocational education in the period after the restoration of independence of Latvia can be divided into three stages:

1. Vocational training between 1995 and 1998. During this period, the basic principles of education are determined by the Education Development Programme (1998 - 2003). Its preconditions are based on the Phare programme and the management of the transition program in Latvia.

2. Vocational education in the period from 1999 to 2001.

3. Vocational training for the period 2002-2005. During this period, the Concept of Educational Development 2002-2005 is operational. It aims to promote a knowledge-based democratic and socially integrated society and an increase in the competitiveness of the economy (Gosh, 2007).

Reducing the unemployment rate and increasing the competitive labour force are processes that can be viewed together in the context of 
vocational education and work-based learning. In itself, vocational education is an instrument for the entry into the labour market of specialists of the appropriate level with the skills and competencies they will need in carrying out their duties in the labour market (Vjakse, 2020). The above-mentioned Vocational Education Law, which also applies to higher vocational education, states that the level of professional qualification acquired by an educate upon graduation from such an educational institution is his theoretical and practical training, which allows him or her to perform work duties of a certain complexity. The professional competencies laid down in the Law are, in turn, a set of knowledge, skills and responsibilities necessary for the performance of professional activity in a specific work situation. Such competencies are acquired during the training practice, where the acquisition of the practical part of studies is implemented in an educational institution or outside it. Meanwhile, the trainee himself is defined in the law as an educate who, according to the acquisition of the practical part of the relevant vocational education program, is in training practice in an institution, merchant or association (Vocational Education Law, 1999).

The concept developed by the Ministry of Education and Science in 2009 to increase the attractiveness of vocational education and promote the active involvement of social partners envisages the improvement of the efficiency and quality of vocational education. Vocational education programs are mainly implemented in educational institutions, but practical training - in educational institutions or companies (Cedefop, 2015).

Since 2012, in the context of vocational education, work-based learning has begun to be introduced in Latvia, when the Ministry of Education, by signing a memorandum on cooperation in the field of vocational education in Europe, starts supporting such a model of education. It envisages a new form of apprenticeship education. In 2013, such a learning model is introduced in six different vocational education programs. The acquisition of education is based on two stages, firstly, the acquisition of theoretical knowledge in a vocational education institution, secondly - the acquisition of skills and compositions in an enterprise or real working environment. The successful implementation of the project in Latvia opened up opportunities for further development of such an educational model (Cedefop, 2015).

Officially, studies based on the environment in Latvia were introduced in 2015, when the Employers Confederation of Latvia began to implement such a training model in vocational education, providing for tripartite cooperation between educates, educational institutions and employers (ESF project Participation of students of vocational education institutions in work-based learning and training practices in enterprises, 2020). 


\section{Method}

In order to find out the historical development related to the research topic, which is rooted in historical evidence, regulation of regulatory enactments and the dominant concepts in this field, historical literature sources, Latvian regulatory enactments and statistical data were analyzed. Based on the keywords - higher education, lifelong learning, vocational education, work environment, work-based learning, articles and periodical sources were found that provide evidence, describing the historical development of work-based learning in vocational education in Latvia. The conclusions presented in this article will form the basis for further research on the work environment-based study process model for the second level higher professional education in the field of health care for obtaining the qualification of a general care nurse.

\section{Conclusions}

Although the term 'work-based learning' is already ingrained in today's society in 2015, the concepts of "project method" "real-life implementation" "real activities" "polytechnic education" etc. were used to reflect this form of education.

The origins of work-based learning in Latvia can be found already $14-15^{\text {th }}$ century. In modern terms, it is first realized in Soviet times, when the testimonies of the history of 1976 analyze about getting to know work experience as an integral part of communist work schools. In its early days, work-based learning can be considered a decentralised process where working skills are acquired from an already practising craftsman. At later stages of history, such a form of education is inseparable from vocational education, the beginnings of which in Latvia are considered to be the establishment of the Riga Polytechnic School $19^{\text {th }}$ century. Agriculture and crafts have been the driver of vocational education in Latvia through the times, resulting in $20^{\text {th }}$ century he 1960 s and 1970 s, training classes were introduced in manufacturing enterprises in Latvia with the aim of bringing young specialists closer to the requirements of the particular labour market and promoting economic productivity. It can be said that vocational education institutions in Latvia are inherited from the education policy of the Soviet Union when vocational schools were closely related to large industrial enterprises in different sectors of the economy.

After regaining independence, vocational education in Latvia is mainly based on the Phare program and the management of the transition program in Latvia, which is later included in the Education Development Strategy 
with the aim of promoting the improvement of the competitiveness of the national economy.

Since 2015, Work-Based Learning has been included in the Vocational Education Act as a separate form of acquisition of this education. Although work-based learning is no longer a new phenomenon secondary professional education level, such a study model is now increasingly being developed in high vocational education. In higher vocational education, a workbased educational process is currently being integrated into qualification practices. However, in professions such as 'teacher' and 'nurse', the first approbations of work-based study programs have already begun.

Work-based learning has, since its inception, reflecting the public's perceptions of the specialities needed in the labour market at the time. The main factor in the development of work-based learning, which over the years has led to the introduction of such a training model in Latvia - the ack of the quality labour force. The results of this report will be used in the future to carry out a study on the implementation of the work-based study process in the higher vocational education of nurses.

\section{References}

Andrejsons, V. (1958). Work - the basis of learning and knowledge. Soviet Youth, No. 168. http://periodika.lv/periodika2viewer/?lang = fr\#panel:pa|issue:175372|article: DIVL178|query:DARBS\%20mācīšanās\%20un\%20zināšanu\%20pamats

Active meeting of trade unions. (1944). Zemgale Communist, 10. http://periodika.lv/periodika2viewer/?lang = fr\#panel:pa|issue:279344|article:DIVL105|query:arodbiedrību\% 20aktivia\%20sanāksmes

Attenborough, J., Abbott, S., Brook, J., \& Knight, R. A. (2019). Everywhere and nowhere: Work-based learning in healthcare education. Nurse Education in Practice, 36, 132-138. https://doi.org/10.1016/j.nepr.2019.03.004

Beck, R. H. (1990). Polytechnical education: A step. Berkley: National Centre for Research in Vocational Education.

Cedefop (2015). Vocational education in Latvia: Short description. Luxembourg: Publications Office of the European Union. Cedefop information series.

Dewey, J. (1938). Experience and education. New York: Macmillan.

Dindan, p. (1921). What needs to be done for the development of horticulture in Latvia. Farmer, No. 1-2. http://periodika.lv/periodika2viewer/?lang = fr\#panel:pa|issue:81983| article:DIVL154|query:P\%20Dindans

Ministry of Economics. (2018, February). Supports the application of light conditions for attracting highly qualified specialists from abroad. https://www.mk.gov.lv/lv/ jaunums/mk-atbalsta-atvieglotu-nosacijumu-piemerosanu-augsti-kvalificetu-specialistupiesaistei-no-arvalstim

ESF project. (2020). Participation of students of vocational education institutions in workbased learning and training practices in enterprises. SAM 8.5.1.0/16/I/001. https://lddk.lv/ atbalsts-biznesam/partneriba-un-lidzdaliba-es-projektos/darba-vide-balstitas-macibas/ 
Gosh, Z. (2007). Development of vocational education and compliance with labour market requirements in Latvia. Articles of the University of Latvia 2007, Volume 718 Economics VI, pp. 116-133.

Ministry of Education and Science. (2020, January). Work-based study programme for teacher training: implementation and development. Information message. Ministry of Education and Science of the Republic of Latvia. http://tap.mk.gov.lv/lv/mk/tap/?pid= 40476411

Kilpatrick, W. H. (1918). The project method. New York: Teachers College, Columbia University.

Kestere, I. (2019). Adult education in Latvia: Historical development and current problems. https://epale.ec.europa.eu/lv/blog/pieauguso-izglitiba-latvija-vesturiska-attistiba-unaktualas-problemas

Ministry of Welfare (2021). Classification of occupations. Updated February 22, 2021. https://www.lm.gov.lv/lv/klasifikacija/profesiju-klasifikators/profesiju-klasifikatorsaktualizets-2021gada-22februari

Latvia 2030 (2010). Sustainable Development Strategy of Latvia until 2030. Latvijas Vēstnesis, 28.04.2009, No. 65. https://www.vestnesis.lv/ta/id/191187

Latvijas Vēstnesis (1995). Report of the Republic of Latvia to UNESCO Education for All. Latvijas Vēstnesis, 22.11.1995, No 181. https://www.vestnesis.lv/ta/id/27670

Latvijas Vēstnesis (2020). Ourselves - from scale fire to kerosene lamp and electricity. Latvijas Vēstnesis, 30.11.2000, No. 432434. https://www.vestnesis.lv/ta/id/13176

Saeima of the Republic of Latvia (1995). Law on Higher Education Institutions. Latvijas Vēstnesis, 179, 17.11.1995. Retrieved from: https://likumi.lv/ta/id/37967augstskolu-likums

Saeima of the Republic of Latvia (1999). Vocational Education Law. Latvijas Vēstnesis, 213-215, 30.06.1999. Retrieved from: https://likumi.lv/ta/id/20244-profesionalasizglitibas-likums

State Audit Office of the Republic of Latvia. (2019, July 3). Human resources in health care. riga. Retrieved August 9, 2021 from: https://www.lrvk.gov.lv/lv/revizijas/revizijas/ noslegtas-revizijas/cilvekresursi-veselibas-aprupe

National Encyclopedia (2020). Vocational education in Latvia. https://enciklopedija.lv/ skirklis/5274-arodizglītība-Latvijā

National Encyclopedia (2021). Higher education in Latvia. https://enciklopedija.lv/ skirklis/10214-augstākā-izglìtība-Latvijā

Raelin, A. J. (2008). Work-based learning: Bridging knowledge and action in the workplace. New and Revised Edition. Jossey-Bass, A Willey Company, San Francisco.

Skujenieks, M., ed. (1938). Latvian cultural statistics. 1918-1937 [Statistics of Latvian culture. 1918-1937]. Riga: State Statistical Bureau, p 94.

Scherbakov, A.Sh. (1941). At Lenin's bequests. Work, No. 25, Riga. http://periodika.lv/ periodika2viewer/?lang = fr\#panel:pa|issue:263208|article:DIVL5|query:Pēc\%20 L,eñina\%20novēlējumiem\%20Lenina

Turkovsky, J. (1976). Classroom at the workplace. October flag (Aluksne), No. 138. http://periodika.lv/periodika2viewer/?lang = fr\#panel:pa|issue:466248|article: DIVL82|query:MĀCĪBU\%20KLASE\%20DARBA\%20VIETA\%20darba 
Vjakse, J. (2020). LDDK: work-based learning is an opportunity to complete higher education studies.https://epale.ec.europa.eu/lv/blog/lddk-darba-vide-balstitas-macibas-iraugstakas-izglitibas-studiju-pilnveides-iespeja

Wagner, R., \& Childs, M. (2000). Work based learning as critical social pedagoguy. AVETRA Conference Papers 2000. 